UDC [37: 001.8]: 519. 22/. 25

DOI: https://doi.org/10.35619/iiu.v0i9.148

\author{
Volodymyr Rudenko \\ Doctor habilitowany, Professor, \\ Kierownik Katedry Pedagogiki, \\ Wyższa Szkoła Menedżerskiej w Warszawie, \\ Warszawa, Polska \\ ORCID: 0000-0001-5986-264X \\ e-mail:vrudenko2004@gmail.com
}

\title{
METODOLOGIA STOSOWANIA STATYSTYKI MATEMATYCZNEJ W BADANIACH PEDAGOGICZNYCH
}

Adnotacja. W pedagogice ważne są metody statystyki matematycznej stosowane na różnych etapach organizacji i badań nad edukacją: dla kształtowania prób losowych, wyznaczenia głównych wskaźników statystyki opisowej, w trakcie wnioskowań statystycznych z użyciem metod analizy korelacji i regresji, wariancji i czynników.

Słowa kluczowe: statystyka, metodologia, metoda, edukacja, pedagogika, badania.

Sformulowanie problemu. Maematyzacja badań naukowych jest charakterystyczną cechą współczesnej nauki. Obecnie można obserwować przyśpieszony rozwój wiedzy fundamentalnej, metod analityczno-jakościowych i porównawczo-ilościowych, analizy danych empirycznych i systematycznego użycia potencjału komputerowego. W znacznej mierze rozszerza to możliwości poznania naukowego. Całkiem oczywiste jest, że i współczesny pedagog musi znać istniejący arsenał nauki.

Celowość użycia metod matematycznych w pedagogice dziś nie poddaje się w wątpliwość. Badania pedagogiczne $\mathrm{z}$ dołączeniem matematyki są skierowane na ujawnienie prawidłowości naukowej działalności oświatowej, wyznaczenie środków kształcenia, wychowania i rozwoju osobistego. W ciągu ostatnich lat pedagogika w znacznej mierze przeszła od etapu gromadzenia materiału empirycznego do jego systematyzacji, uogólniania, uświadomienia, interpretacji strukturalnej, konceptualizacji i paradygmatyzacji. Użycie metod matematycznych w pedagogice pomaga opracowywać, analizować i interpretować dane w celu otrzymania odpowiedzi na stawiane pytania, założone przypuszczenia naukowe, sformułowane hipotezy. Matematyka jest więc efektywnym środkiem poprawy rozumienia i projektowania procesów kształcenia i wychowania.

Zastosowanie matematyki $\mathrm{w}$ pedagogice proponuje się rozpatrywać systemowo i jako naukowo-uzasadnioną ocenę działalności pedagogicznej oraz środek wzmacniania możliwości; jako symboliczną formę budowy modeli realności pedagogicznej dla jej analizy i udoskonalenia; jako perspektywiczne podejście do prognozowania rozwoju systemów oświatowych w celu ich optymalizacji. Dla pedagoga, który planuje użycie matematyki we własnej działalności fachowej, jest ważnym nie tylko posiadanie aparatu matematycznego, ale również wiedza $\mathrm{w}$ zakresie technologii, strategii i taktyki zastosowania konkretnych metod statystycznych w celu naukowym lub praktycznym.

Jak wiadomo, nauczenie się wykorzystywania metod matematycznych jest zawsze zadaniem bardziej skomplikowanym, aniżeli przyswojenie gotowych formuł 
matematycznych. Co więcej, sam proces ich użycia nierzadko przekształca się w pełnowartościowe badanie. Włącza ono opracowanie modelu koncepcyjnego, formułowanie celu i zadań, uściślenie obiektu, spełnienie obserwacji albo działań eksperymentalnych dla uzyskiwania danych empirycznych, wybór adekwatnych środków matematycznych, obliczenie wskaźników cechy, weryfikację zdobytych wyników i ich interpretację, ocenę efektywności badania i wiele innych działań.

Przedstawienie głównego materiału badawczego. Matematyzacja nauk - to wsparcie różnych zakresów badania naukowego adekwatnymi metodami matematycznymi. Poziom matematyzacji uważa się za jeden z najważniejszych wskaźników rozwoju pewnej branży naukowej. Metodologia poznania naukowego wydziela trzy etapy matematyzacji nauk.

- $\mathrm{Na}$ pierwszym etapie następuje opracowanie surowego materiału empirycznego ("faktów ustalonych"). Główny cel tego etapu - "ściskanie" informacji dla przedstawienia jej w sposób najbardziej spoisty. Wynikami tego etapu są klasyfikacje empiryczne, uogólniania, tendencje zmienności statystycznej i inne. Opis ilościowy jest przesłanką późniejszego wyjaśnienia i prognozy w ramach pewnej teorii. $\mathrm{Na}$ tym etapie metody matematyczne są członem poznania empirycznego, lecz nie mają znaczenia samodzielnego w rozwijaniu schematów teoretycznych.

- Drugi etap matematyzacji to opracowanie i sprawdzenie cząstkowych modeli matematycznych, które objaśniają i prognozują "zachowanie" obiektu badanego w pewnych sytuacjach, przy pewnych dopuszczeniach i warunkach. Te modele są schematami formalno-logicznymi. Zabezpieczają one dedukcyjne wnioski, które ciężko albo niemożliwością jest otrzymać bez użycia matematyki. To, najpierw, są wnioski statystyczne na podstawie różnych testów statystycznych, metod analizy wariancji, korelacji, regresji i inne.

- Trzeci etap charakteryzuje się stworzeniem ogólnego modelu matematycznego, dającego wyczerpujący opis różnych stanów, w których może znajdować się obiekt badany. Teorię matematyczną danego poziomu organizacji można uważać za statystyczną teorię testowania pedagogicznego. Jej wykorzystanie daje możliwość otrzymania kilku różnych modeli oceniania osób oraz sprawdzenia jakości materiału dydaktyczno-testowego.

Etapy matematyzacji odpowiadają trzem teoretycznym fazom nauki: empirycznemu - przejściowemu - teoretycznemu. Na tych fazach opiera się jakościowe przekształcenie wiedzy naukowej: od "obserwowanych" danych do konstrukcji teoretycznych; od klasyfikacji empirycznych do uogólnień teoretycznych; od pierwotnych opisowych koncepcji do teorii wyjaśniających i prognozujących; od prawidłowości empirycznych do praw teoretycznych.

Użycie matematyki na tych fazach różni się. Empirycznej fazie odpowiada pierwszy etap matematyzacji (analiza danych otrzymanych na podstawie "pierwotnej interpretacji”). Przejściowa fazę można naturalnie zestawić z drugim etapem matematyzacji - opracowaniem "cząstkowych" modeli matematycznych. Fazę rozwiniętej nauki teoretycznej można związać $\mathrm{z}$ trzecim etapem - budową "ogólnych" modeli matematycznych. Wymienione wyżej etapy mogą być sygnalizowane podczas analizy istniejących typów wykorzystania matematyki we współczesnej nauce pedagogicznej. Jednak w pedagogice wciąż dominuje naprawdę opisowe użycie matematyki, jako środka wygodnego dla wyrażenia konkretnych idei, bez poważnych prób zastosowania dedukcji matematycznej dla prognozowania rzeczywistości pedagogicznej. 
Znaczną rolę we wprowadzeniu metod matematycznych do badań socjalnohumanistycznych ( $\mathrm{w}$ tym również $\mathrm{i}$ do pedagogiki) odegrały teoria prawdopodobieństwa i statystyka matematyczna, które od momentu powstania rozszerzały zakres swojego stosowania na rozwiązanie problemów społeczeństwa, człowieka, cech osobowości, jego zdolności i zachowania. Przykładami są "Arytmetyka polityczna" (Petty, 1691, c. 8), "Doświadczenie arytmetyki moralnej" (Georges de Buffon - XVIII st.) (Trzecia chrestomatia $\mathrm{z}$ historii teorii prawdopodobieństwa i statystyki), „Social fizyka, lub doświadczenie w pracy nad rozwojem zdolności ludzkich" (Adolph Quetelet - XIX st.) (Ketle 1911-13) i wiele innych prac.

Dołączenie tych metod spowodowane było nie wewnętrzną logiką rozwoju naukowych idei psychologii i pedagogiki, lecz subiektywną chęcią, życzeniem zastosowania metody oceny prawdopodobieństwa oraz metod statystycznych do zjawisk o charakterze humanitarnym na podstawie "zdrowego rozsądku". Dopiero od XX st. zaczyna się celowe opracowanie i efektywne użycie metod statystycznych dla analizy danych empirycznych (podczas pomiaru, sprawdzenia hipotez, ustalenia związków przyczynowo-skutkowych $\mathrm{i}$ innych). Pojawiają się takie potężne wielowymiarowe metody statystyczne, jak analiza czynników, do opracowania której w fazie początkowej przyczynił się Charles Spearman, analiza wariancji, związana z imieniem Roberta Fishera i inne metody.

Matematyzacja pedagogiki $\mathrm{w}$ porównaniu $\mathrm{z}$ analogicznymi procesami, co obserwujemy, na przykład, w psychologii, odbywała się wolniej. Dopiero w pierwszej połowie XX st. w związku z intensywnym wprowadzeniem do nauki matematyki, i pedagodzy zaczęli pokładać niewielką nadzieję w metodach ilościowych. Pedagogika "nie poddawała się", nie zważając na to, że od drugiej połowy XX stulecia stosowanie metod matematycznych miało już miejsce wśród pedagogów (Siegel, 1956; Glass, Stanley, 1970; Guilford, 1980; Brzeziński, 1996; Ferguson \& Takane, 1997). Było oczywiste, że te metody są potrzebne i pożyteczne, lecz nie obyło się rewolucji. Wprowadzenie metod matematycznych napotykało w pedagogice na jakąś obiektywną przeszkodę. Wkrótce sytuacja wyjaśniła się: te metody, zdaniem W. Ledniowa, "pracują" tylko w jedności z modelowaniem systemowym, jednak przebywają $\mathrm{w}$ tej symbiozie na "rolach drugorzędnych" (Ledniow, 2002. s. 7).

W końcu XX wieku szczególną uwagę zaczęto poświęcać związkowi metodologii badań pedagogicznych $\mathrm{z}$ intensywnym rozwojem nauki ogółem i w pierwszej kolejności z podejściem systemowym. Z czasem metody matematycznostatystyczne (analiza regresji, korelacji, czynników i inne) zaczęły otrzymywać status poszczególnej grupy metod badawczych.

STATYSTYKA MATEMATYCZNA W SYSTEMIE METOD PEDAGOGIKI. W pedagogice rozróżnia się trzy poziomy badań: empiryczny, teoretyczny i metodologiczny. Na pierwszym poziomie ustalane są nowe fakty nauki, na podstawie uogólniania których formułuje się prawidłowości empiryczne. Na drugim - wysuwa się i formułuje główne ogólne prawidłowości pedagogiczne, co pozwala wyjaśnić przedtem znane fakty oraz prognozować i przewidywać przyszłe zdarzenia. $\mathrm{Na}$ trzecim poziomie, metodologicznym, na podstawie badań empirycznych i teoretycznych formułuje się ogólne zasady badań pedagogicznych.

Najbardziej rozpowszechnione $\mathrm{w}$ pedagogice są badania empiryczne $\mathrm{i}$ teoretyczne. Pierwsze są kierowano bezpośrednio do obiektu pedagogicznego (zjawiska, procesy) i opierają się na danych obserwacji i eksperymentów. Drugie są 
związane z udoskonaleniem i rozwojem bazy pojęciowej i aparatu kategorii pedagogicznych i skierowane na poznanie rzeczywistości pedagogicznej w jej istotnych związkach i prawidłowościach.

W badaniach naukowych nad edukacją wydziela się takie metody:

- empiryczne (eksperyment, pomiar, obserwacja, ankietowanie, sondaż), za pomocą których spełnia się realne współdziałanie między podmiotem i przedmiotem badania, wynikiem tego są dane, które utrwalają stany obiektu;

- teoretyczne (indukcja i dedukcja, analiza i synteza, klasyfikacja, modelowanie), gdy podmiot współdziała z domniemanym (abstrakcyjnym)obiektem; wynikiem jest teoria, prawidłowość, hipoteza indukcyjna, model obiektu, procesu, stanu;

- interpretacyjne, według których podmiot z "zewnątrz" współdziała ze znakowo-symbolicznym przedstawieniem obiektu (formułami, grafikami, schematami itp.) w rezultacie wynikiem staje się współdziałanie metod eksperymentalnych i teoretycznych;

- statystyczne (opis i wnioskowanie, testowanie hipotez statystycznych, analiza korelacji, analiza czynnikowa i inne).

W tej klasyfikacji pierwsze trzy grupy metod można uważać za klasyczne, dla których procedury statystyczne w pewnej mierze mają miejsce prawie we wszystkich grupach metod. W badaniach pedagogicznych za pomocą statystyki można otrzymać uogólnione informacje co do obiektów badanych, obliczyć wskaźniki związku i wpływu, ujawnić prawidłowość w rozwoju procesów. Statystyka pełni specjalne funkcje metod naukowych opisu i poznania zjawisk pedagogicznych. Metody statystyczne nie zastępują tradycyjnych metod pedagogicznych, one je uzupełniają, wzbogacają i rozszerzają, zwłaszcza w otrzymywanych dowodowych wynikach. Istnieją jednak inne punkty widzenia dotyczące miejsca statystyki w badaniach pedagogicznych. Na przykład, schematy badań pedagogicznych metodami statystycznymi (doboru prób, zbierania i analizy danych), zdaniem Krzysztofa Rubachy, odnoszą się do metod empirycznych, po użyciu których odbywa się interpretacja wyników badania (Rubacha, 2008, s. 34-37).

Miejsce metod statystycznych można określić ocenę struktury procesu badawczego:

1. Sformułowanie problemu badawczego oraz hipotezy badawczej.

2. Określenie obszaru przestrzeni zmiennych.

3. Operacjonalizację zmiennych.

4. Wybór modelu badawczego (eksperymentalny lub korelacyjny).

5. Dobór próby z populacji.

6. Wybór modelu statystycznego (t-test, F-test, $\chi 2$-test, ANOVA lub MANOVA, wielokrotnej regresji, inne).

7. Akceptację lub odrzucenie hipotezy.

8. Ocenę, interpretację, generalizację rezultatu badawczego (Brzeziński, 2003, s. 37-44).

Metody statystyczne wchodzą więc organicznie do procesu badawczego. Autor uważa że ich obecność jest ważna w składzie innych metod. Analogiczne podejście prezentuje większość badaczy (King \& Minium, 2009; Francuz \& Mackiewicz).

Wyjątkowość i warunki stosowania statystyki w badaniach pedagogicznych opierają się na zasadach:

- teoretycznych przepisach nauki pedagogicznej; 
- uświadomieniu specyfiki podejścia pozytywistycznego (nomotetycznego) i fenomenologii (podejścia ideograficznego) w badaniach pedagogicznych;

- użyciu metod matematycznych i klasycznych metod badań pedagogicznych;

- uwzględnieniu możliwości i ograniczeń modelowania matematycznego zjawisk i procesów wychowania i kształcenia;

- stosowaniu statystyki dla danych, otrzymanych praktycznie wszystkimi znanymi metodami badań;

- wcześniejszym planowaniu i organizacji badań, opracowaniu procedur pomiaru, uściśleniu metod konkretnych;

- dodatkowym wykorzystaniu metod międzydyscyplinarnych, np. analizy treści (kontent-analizy), ankiet-wywiadów, pomiarów socjometrycznych i innych.

TYPY POMIARÓW W PEDAGOGICE. Pomiar jest nadaniem obiektowi czy jego właściwościom liczby według pewnej reguły. W badaniach pedagogicznych wykorzystujemy cztery typy skal pomiaru: nominalną, porządkową, interwałową $\mathrm{i}$ stosunkową (Stevens, p. 677-680).

Dla skali nominalnej jedyną dozwoloną procedurą pomiarów jest klasyfikacja właściwości obiektów badania według pewnej kategorii (np. płci, religii, narodowości i innych). Zmienne wymierzone przez skalę nominalną nie są ilościowe. Można je porównywać pomiędzy sobą tylko na podstawie ilości obserwacji. Pewna kategoria nie może być wyższa lub niższa nią inna.

Wymagania adekwatności pomiarów nominalnych są następujące:

- kategorie zmiennych nominalnych muszą być wyłączające wzajemnie, by nie istniało nieokreśloności co do klasyfikacji obiektu;

- kategorie muszą być wyczerpujące: każdej możliwej wartości musi odpowiadać pewna kategoria (chociażby kategoria "inne");

- kategorie zmiennych nominalnych muszą być jednorodne, czyli włączać egzemplarze, które można zestawiać.

Skala porzadkowa pozwala nie tylko klasyfikować obiekty, lecz i sortować je w kolejności rosnącej lub malejącej właściwości. Dla zmiennych porządkowych możemy zaobserwować fakt, że wartość pewnego obiektu jest większą lub mniejszą, aniżeli wartości innych. W skali porządkowej można zmiennym przypisywać liczby - czynność taka jest znana jak rangowanie.

Główne ograniczenie skali porządkowej polega na tym, że każda oddzielna wartość charakteryzuje się tylko położeniem co do innej wartości. Można odróżnić wysoki poziom od niskiego, jednak nie można opisać inności między nimi w dokładnych jednostkach.

Skala interwałowa dopuszcza nie tylko klasyfikację i sortowanie, lecz dokładne wyznaczenie różności między wartościami. Dla zmiennych interwałowych zawsze można sprecyzować miarę tego, na ile jedna zmienna się różni (więcej lub mniej) od innej. Ważna cecha pomiarów interwałowych polega na tym, że właściwość obiektu nie znika, jeśli wskutek pomiaru zmienna nabywa wartości zerowej.

Skala stosunkowa ma wszystkie właściwości skali interwałowej i do tego ma utrwalony początek odliczania. Wartość zerowa dla takich zmiennych wskazuje na pełną nieobecność tego, co się mierzy. Stosowanie metod statystycznych wymaga różnych operacji, więc skala pomiaru jest pierwszym wskazaniem wyboru cechy badanej i odpowiedniej zmiennej. 
Skala pomiarów jest więc jedną z głównych charakterystyk zmiennych, która uwzględnia się podczas wyboru tej czy innej metody matematycznej. Istnieją jednak dodatkowe właściwości użycia skal pomiarowych, powiązanych z dopuszczalnymi procedurami przekształceń matematycznych. Są one określone współzależnościami przyrodniczo-naukowymi (nomotetycznymi) i humanistycznymi (ideograficznymi) paradygmatami badań pedagogicznych. Nomotetyczny sposób jest orientowany na odkrycie prawidłowości ogólnej, sprawiedliwej dla jakiejkolwiek części zjawiska, ideograficzny jest skierowany na opis i wyjaśnienie całego skomplikowanego przedmiotu, na przykład, konkretnej unikalnej osobowości. Charakterystyki skal pomiaru są przedstawiane w tabeli 1 .

Tabela 1.Charakterystyki skal pomiaru

\begin{tabular}{|c|c|c|c|}
\hline Skala & $\begin{array}{c}\text { Cechy (wskaźniki } \\
\text { statystyczne ) }\end{array}$ & $\begin{array}{c}\text { Procedury } \\
\text { Pomiaru }\end{array}$ & $\begin{array}{c}\text { Dozwolone } \\
\text { operacje matematyczne }\end{array}$ \\
\hline Nominalna & $\begin{array}{l}\text { Płeć, rasa, religia, } \\
\text { stan rodzinny } \\
\text { (kategorie) }\end{array}$ & $\begin{array}{l}\text { Klasyfikacja } \\
\text { obiektów }\end{array}$ & $\begin{array}{l}\text { Obliczenie i porównanie } \\
\text { ilości obserwacji w każdej } \\
\text { kategorii zmiennej }\end{array}$ \\
\hline Porządkowa & $\begin{array}{l}\text { Wykształcenie, } \\
\text { stopień zadowolenia, } \\
\text { stadium choroby, } \\
\text { właściwości } \\
\text { stosunku, (mediana, } \\
\text { centyle, kwartyle) }\end{array}$ & $\begin{array}{l}\text { Uporządkowywanie } \\
\text { obiektów za pewną } \\
\text { oznaką }\end{array}$ & $\begin{array}{l}\text { Wszystkie } \\
\text { powyżej, a także porównionione } \\
\text { typu "więcej niż" i "mniej } \\
\text { niż" }\end{array}$ \\
\hline Interwałowa & $\begin{array}{l}\text { Poziomy osiągnięć } \\
\text { edukacyjnych } \\
\text { (średnia } \\
\text { arytmetyczna, } \\
\text { odchylenie } \\
\text { standardowe) }\end{array}$ & \begin{tabular}{l}
\multicolumn{2}{l}{ Wyznaczenie } \\
inności między \\
obiektami ra na \\
podstawie równych \\
jednostek- \\
interwałów
\end{tabular} & 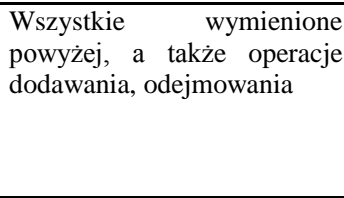 \\
\hline Stosunkowa & $\begin{array}{l}\text { Wiek, wzrost, ilość } \\
\text { dzieci, ilość błędów } \\
\text { w teście, szybkość } \\
\text { reakcji (wariancja) }\end{array}$ & \begin{tabular}{lr}
\multicolumn{2}{l}{ Wyznaczenie } \\
inności między \\
obiektami r na \\
podstawie równych \\
jednostek- \\
stosunków \\
\end{tabular} & $\begin{array}{lr}\text { Wszystkie } & \text { wymienione } \\
\text { powyżej, a także operacje } \\
\text { mnożenia, } \\
\text { pierwiastka kwadratowego }\end{array}$ \\
\hline
\end{tabular}

Metody matematyczne $\mathrm{z}$ użyciem skal interwałów i stosunków w znacznej mierze są właściwe podejściu nomotetycznemu. Podejście ideograficzne jest założone na zasadach osiągnięcia unikalnego i skierowane na jednolite obiekty (np. modelowania osobowości i wszechstronnej realności pedagogicznej itp.). Opis ideograficzny jest maksymalnie pełny i konkretny, pojedyncze elementy postrzega się w nim jako unikalne fenomeny, znaczące miejsce zajmują pomiary nominalne $\mathrm{i}$ porządkowe.

METODY STATYSTYCZNE W BADANIACH EKSPERYMENTALNYCH. Planowanie $i$ organizacja badań eksperymentalnych spetnia pewne założenia (Campbell \& Stanley, 1963), zasady doboru osób do prób eksperymentalnych i kontrolnych,

- bodźce, którym będą poddawani uczestnicy eksperymentu,

- sposoby kontroli przed i po eksperymencie,

- statystyczne metody opracowania danych empirycznych. 
Odpowiednio do cechy badania, można wyróżnić plany (schematy) eksperymentów:

- Eksperyment rzeczywisty polega na tym, że badacz pragnie ustalić związki przyczynowo-skutkowe między głównymi zmiennymi, kontrolując zmienne zewnętrzne dokładnie i systematycznie.

- Quasi-eksperyment jest sposobem organizacji działania, gdy się nie udaje zrealizować planu badania idealnego lecz te wady częściowo kompensuje się użyciem szczególnych schematów oraz dołączeniem innych metod.

- Plany badania korelacji są odmianą planów quasi-eksperymentalnych przy nieobecności działania zmiennej niezależnej na zmienne zależne, ponieważ wszystkie zmienne są zależne. Czynnikiem, który wyznacza tę zależność, może być jedna ze zmiennych lub jakaś zmienna utajona ("trzecia"). Odpowiednio do planu badania korelacji wysuwa się hipotezę o obecności związku statystycznego między kilku cechami osób czy ich zachowania, albo między pewnymi procesami pedagogicznymi, wskaźnikami stanu indywiduum itp. Przypuszczenia co do zależności przyczynowej nie omawia się.

Związek wskaźników zmiennej zależnej, metod i testów statystycznych od typów badań i ilości poziomów zmiennych niezależnych pokazano w tabeli 2 .

Kolejność etapów badania eksperymentalnego w pedagogice:

- Wyznaczenie tematu badania określa sferę problemów badania, następuje uściślenie i wybór obiektu oraz przedmiotu, celów i zadań, formułowanie hipotezy badawczej i dobór odpowiednich metod. Badanie eksperymentalne sprawdza się $\mathrm{w}$ trzech głównych wypadkach i jest związane, z reguły, ze sprawdzeniem hipotez: o istnieniu zjawiska (fenomenu), o istnieniu związku zjawisk, o przyczynowoskutkowej zależności zjawisk.

Eksperyment właśnie stosuje się dla ujawnienia przyczynowego związku zjawisk. Na przykład, w pierwszych miesiącach nauczania możliwe główne przyczyny szkolnej dezadaptacji dzieci w wieku 6-7 lat są takie: niski poziom gotowości do działalności edukacyjnej; niedostateczny rozwój dowolności procesów psychicznych; niski poziom intelektu. Każda z tych potencjalnych przyczyn wymaga sprawdzenia, chociaż wszystkie one zdają się być uzasadnionymi i prawdopodobnymi.

Tabela 2.Metody matematyczne i typy badań eksperymentalnych

\begin{tabular}{|c|c|c|c|c|}
\hline \multirow[b]{2}{*}{$\begin{array}{l}\text { Typy } \\
\text { badań }\end{array}$} & \multicolumn{2}{|c|}{ Zmienne niezależne : } & \multirow[b]{2}{*}{$\begin{array}{c}\text { Wskaźniki } \\
\text { zmiennej zależnej }\end{array}$} & \multirow[b]{2}{*}{$\begin{array}{l}\text { Metody i testy } \\
\text { statystyczne }\end{array}$} \\
\hline & Ilość & $\begin{array}{c}\text { ilość } \\
\text { poziomów }\end{array}$ & & \\
\hline \multirow{2}{*}{$\begin{array}{l}\text { Eksperyment } \\
\text { rzeczywisty }\end{array}$} & \multirow{2}{*}{1} & 2 & \multirow{4}{*}{ Statystyka opisowa } & $\begin{array}{r}\text { Testy } \\
\text { parametryczne }\end{array}$ \\
\hline & & 3 i więcej & & $\begin{array}{c}\text { Analiza wariancji } \\
\text { jednoczynnikowa }\end{array}$ \\
\hline $\begin{array}{c}\text { Badanie } \\
\text { czynnikowe }\end{array}$ & 2 & 2 i więcej & & $\begin{array}{l}\text { Analiza wariancji } \\
\text { dwuczynnikowa }\end{array}$ \\
\hline \multirow{2}{*}{$\begin{array}{c}\text { Quasi- } \\
\text { eksperyment }\end{array}$} & \multirow{2}{*}{1} & 2 & & \multirow{4}{*}{$\begin{array}{c}\text { Testy parametryczne i } \\
\text { nieparametryczne, } \\
\text { metody } \\
\text { wielowymiarowe }\end{array}$} \\
\hline & & 3 i więcej & Wskaźniki regresji & \\
\hline \multirow{2}{*}{$\begin{array}{l}\text { Badanie } \\
\text { korelacji }\end{array}$} & 2 & & \multirow{2}{*}{$\begin{array}{l}\text { Współczynniki } \\
\text { korelacji }\end{array}$} & \\
\hline & $\begin{array}{c}3 \mathrm{i} \\
\text { więcej }\end{array}$ & & & \\
\hline
\end{tabular}


$\mathrm{Na}$ tym etapie formułuje się albo jedna albo kilka hipotez naukowych (treściwych lub merytorycznych), np. przypuszczenie o tym, że "niski poziom gotowości dziecka do działalności edukacyjnej może być przyczyną utrudnienia (przeszkody) dla jego udanej adaptacji szkolnej".

- Wyznaczenie zmiennych, uściślenie i przeksztatcenie hipotezy treściwej do hipotezy statystycznej pod postacią "jeśli A, to B". Eksperymentator zarządza zmienną niezależną $\mathrm{A}$, zależna zmienna $\mathrm{B}$ się rejestruje. Wyznacza się trzecią zmienną "pośrednią" C, przez którą pedagog "kontroluje" realność, czyli zewnętrzne parametry sytuacji, wpływające na warunki eksperymentu. Zmienne zewnętrzne również mogą wpływać na zmienną zależną w sposób niekontrolowany.

- Wybór metodyki eksperymentalnej, która pozwala: zarządzać zmienną niezależną, rejestrować zmienną zależną, eliminować wpływy zmiennych zewnętrznych lub zachowywać ich stałość. Dla naszego przykładu taką metodyką może być pasywne badanie korelacyjne.

- Planowanie eksperymentu zabezpiecza jego trafności zewnętrzne i wewnętrzne. Wybór planu eksperymentalnego (eksperyment, quasi-eksperyment, badane korelacje itp.) i stosowanie metod matematycznych zależy od hipotezy, ilości zmiennych, warunków badania.

- Dobór próby (randomizowanej prostej lub systematycznej, stratyfikowanej lub zespołowej) powinien jakościowo i ilościowo przedstawiać populacje. Główne typy potencjalnych osób badanych muszą być ekwiwalentnie reprezentowane w grupach eksperymentalnych i kontrolnych.

- Spetnienie eksperymentu składa się z takich etapów: przygotowaniei sprawdzenie środków, sprzętu i materiałów dydaktycznych; uściślenie planu i wcześniejsze wypróbowanie; instruktaż i motywowanie wypróbowywanych, pomoc w problemach osobistych; działanie eksperymentalne z rejestracją zachowania i stanów dzieci.

- Wybór metod statystycznych i opracowanie danych wyznaczane są $\mathrm{w}$ stadium planowania lub przedtem - na etapie wysuwaniu hipotezy eksperymentalnej, która przetwarza się do adekwatnej hipotezy statystycznej.

Pierwotne opracowanie danych wykonuje się metodami statystyki opisowej dla uogólniania i wizualizacji rezultatów. Podczas eksperymentu ilość hipotez może być ograniczona dwoma: główną zerową $\mathrm{H}_{0}$ (hipotezą o "podobieństwie") i alternatywną $\mathrm{H}_{1}$ (hipotezą o "inności"). Z reguły, istnieją "przywiązania" pewnych metod matematycznych do planów eksperymentalnych.

- Wnioskowanie i interpretacja wyników kończą cykl badawczy. Wynikiem badania eksperymentalnego jest przyjęcie albo odrzucanie hipotez statystycznych i odpowiednich hipotez merytorycznych. Interpretacja wniosków odbywa się w terminach hipotezy naukowej.

- Przygotowanie sprawozdania naukowego jest końcowym produktem badania. Badanie uważa się za zakończone, jeśli hipoteza badawcza jest odrzucona albo przyjęta na pewnym poziomie istotności, odpowiedź na problem badania jest otrzymana a wyniki badania przedstawiono w sprawozdaniu naukowym, artykule, monografii.

Sprawdzenie hipotezy eksperymentalnej o związku przyczynowym dwóch zjawisk np. A i B przewiduje teoretyczny poziom analizy sytuacji i formułowanie uogólniania. Eksperymentator modeluje przewidzianą przyczynę, która występuje jako działanie eksperymentalne nad obiektem, podczas gdy obserwację rejestruje się jako reakcję obiektu. Działanie eksperymentalne spowoduje zmianę zmiennej 
niezależnej A, co może być bezpośrednią przyczyną zmian zmiennej zależnej B. Ponadto należy obserwować szereg pewnych oznak związku przyczynowoskutkowego zjawisk A i B:

- obecność związu statystycznego - korelacji - między zmiennymi A i B np. między poziomem werbalnego intelektu i postępom w uczeniu się;

- rozbieżność czasowa przyczyny $i$ skutku oraz przyczyna poprzedza śledztwo. Według metody inności Milla: jeśli po A zawsze pojawia się a, i po Nie-A zawsze pojawia się Nie-a, wtedy A jest przyczyną a;

- związek przyczynowo-skutkowy uważa się za ustalony, jeśli procedura eksperymentalna wyłącza inne możliwości wyjaśnienia związków A i B oraz, jeśli inne alternatywne przyczyny powstania zjawiska B sq nieobecne.

Użycie metod matematycznych można więc uważać za ważną nieodłączną część badań pedagogicznych tak na poziomie empirycznym jak również na teoretycznym poziomie poznania naukowego.

Wnioski. Stosowanie statystyki $\mathrm{w}$ badaniach pedagogicznych zaleca się szeregom zagadnień: problemom naukowym, planom badania; typom skal pomiarów, sposobom kształtowania obiektu badania (grupa czy jedna osoba); sposobem kształtowania próby (dobór randomizowany prosty, stratyfikowany itp.), charakterom rozkładu zjawiska badanego (normalny, niewiadomy), wariantom hipotezy statystycznej i odpowiednim testom jej sprawdzenia i innym.

Wybór wariantu stosowania tych czy innych metod i procedur matematycznych wyznacza się przed badaniami i zależą one od celów, zadań, obiektu, warunków badania. Ogólnym zadaniem statystyki matematycznej w strukturze badania jest opracowanie informacji relewantnej, jednak kluczowy punkt to etap formułowania, przyjęcia-odrzucania, uściślenia hipotezy badawczej. Wariantów przejścia od hipotezy merytorycznej do hipotezy statystycznej może być kilka i wymaga to od badacza podejścia twórczego. Metody matematyczne mogą mieć dwie funkcje: jako instrument uściślenia i udoskonalenia hipotez merytorycznych i jako środek ich sprawdzenia. W rezultacie hipoteza może zdobyć status wiedzy naukowej, która w pewnej mierze posiada właściwości prognozy.

GLÓWNE ZADANIA I METODY STATYSTYKI MATEMATYCZNEJ. Statystyka matematyczna zajmuje się opisem i analizą prawidłowości obserwowanych w procesach masowych oraz opracowaniem i sprawdzeniem ich modeli, które zawierają pojęcie prawdopodobieństwa. Przepisy i zasady teorii prawdopodobieństwa wyznaczają przedmiot i metody statystyki matematycznej. Te metody rozszerzają możliwości podejmowania racjonalnej decyzji w sytuacji, gdy determinowane prognozy są niejasne, ponieważ istotne parametry albo są niewiadomymi albo nie mogą być określone z dostateczną precyzją (Granino, Korn $\&$ Theresa, 2000, s. 665).

W strukturze statystyki matematycznej tradycyjnie wydzielane są dwa główne rozdziały: "Statystyka opisowa" $i$ "Wnioskowanie statystyczne" (rys. 1). 


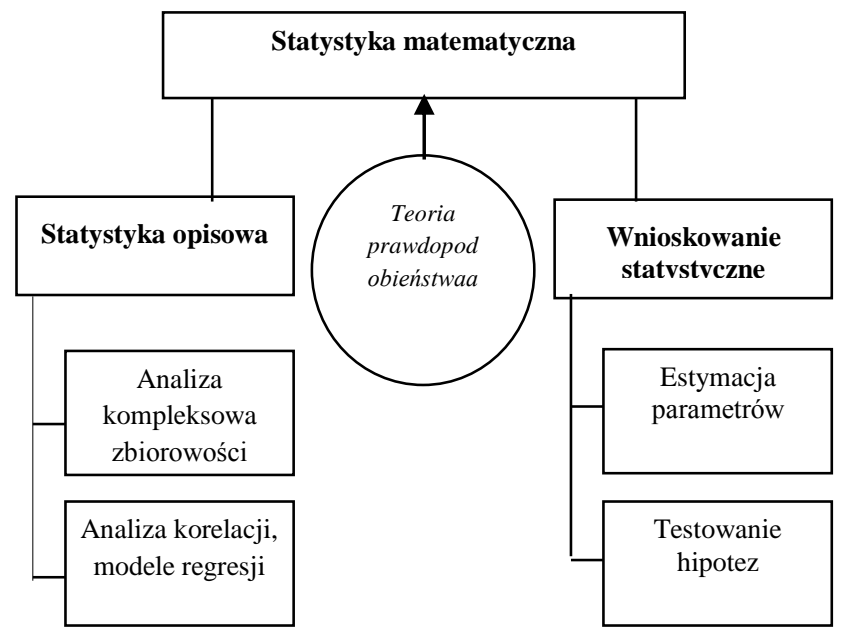

Rysunek 1. Rozdziały statystyki matematycznej.

Statystyka opisowa zajmuje się: losowych;

- analizą kompleksową i uogólnianiem właściwości obiektów prób

- ujawnianiem związków między cechami badanymi oraz dynamiką zjawisk (analiza korelacji, modele regresji, szeregi czasowe i inne).

Statystyka opisowa daje możliwość otrzymania nowej informacji, szybszego zrozumienia i wszechstronnej oceny, czyli wykonuje naukową funkcję opisu obiektów badania, co usprawiedliwia jej nazwę.

Za pomocą metod statystyki opisowej duże ilości danych empirycznych można przekształcić w system naoczny dla postrzegania wykresów i wzorów: rozkładów częstości; wskaźników tendencji, rozproszenia, związków itp., co jest podstawą dla spełnienia wnioskowań statystycznych.

Wnioskowanie statystyczne zajmuje się:

- estymacją (szacowaniem) parametrów populacji, oceną błędów, które powstają w trakcie badań statystycznych;

- testowaniem hipotez statystycznych, uogólnieniem parametrów populacji generalnej, formułowaniem wniosków statystycznych.

Glówny cel badań naukowych z użyciem statystyki matematycznej to otrzymanie nowej wiedzy o dużych rozmiarach zjawisk, osób, zdarzeń, wiedzy o procesach masowych, które przyjęto nazywać populacja generalna.

Pojęcie "populacja generalna" wykorzystuje się dla opisu całokształtu obiektów badanych (np. dzieci w wieku przedszkolnym pewnego okręgu, studenci jakiejś uczelni itp.). Populacja generalna może sięgać znacznej iliści, być skończoną lub nieskończoną. $\mathrm{W}$ praktyce, $\mathrm{z}$ reguły, mamy do czynienia $\mathrm{z}$ całokształtem skończonym. Populacją generalną można nazywać nie tylko pełny całokształt obiektów lecz całokształt wartości cech badanych.

Populacja generalna jest więc zbiorowością obiektów badania, z kolei próba losowa jest jej częścią kształtowaną w pewien naukowo uzasadniony sposób. Przynależność próby do populacji generalnej jest główną podstawą dla oceny 
parametrów populacji według statystyk próby. Statystyki są wskaźnikami próby, parametry są wskaźnikami populacji.

Glówna idea statystyki matematycznej bazuje na przekonaniu, że dla większości naukowych zadań badanie obiektów populacji generalnej w całości jest albo praktycznie niemożliwe albo ekonomicznie niecelowe, ponieważ wymaga dużo czasu i znacznych kosztów materialnych. Dlatego w statystyce matematycznej wykorzystuje się podejście, którego zasady można wyjaśnić za pomocą schematu, przedstawionego na rysunku 2 , a mianowicie:

- z przeznaczonej do badania populacji generalnej za pomocą pewnych metod kształtowania formuje się próbę losową - typową, lecz ograniczoną ilość obiektów, do których stosuje się metody badawcze (pomiary, obserwacji, eksperyment, sondaż i inne);

- zgodnie $\mathrm{z}$ celem badania $\mathrm{w}$ rezultacie obserwacji, eksperymentów i pomiarów nad obiektami próby, otrzymujemy dane empiryczne, które ocenia się jako "surowe";

- opracowanie danych empirycznych za pomocą metod statystyki opisowej daje wskaźniki próby, które nazywają się statystykami;

- za pomocą metod wnioskowania statystycznego otrzymujemy parametry, które już charakteryzują właściwości populacji generalnej.

Przyklad-zadanie. Dla oceny poziomu osiągnięć uczniów (zmienna X) przeprowadzono pracę samodzielną złożoną z kilku zadań. Każde zadanie oceniało się w sposób: "dokonano" - 1, "nie dokonano" - 0. Ustalić, czy tegoroczne średnie osiągnięcia uczniów $\bar{X}$ odpowiadają wartości średniej $\mu$ zeszłych lat?

Rozwiazanie:

Zgodnie ze schematem rysunku 2 kolejność rozwiązań może być następująca:

- $\mathrm{z}$ populacji uczniów liczebnością $\mathrm{N}$ wykonać dobór losowy do próby liczebnością $n$;

- przeprowadzić prace samodzielną w próbie uczniów i otrzymać indywidualne wyniki w poziomach - dane empiryczne $x 1, x 2, \ldots, x n$;

- systematyzować dane empiryczne, utworzyć rozkłady częstości, przedstawić wykresy graficzne rozkładów cechy badanej (zmiennej X);

- obliczyć statystyki - średnią $\bar{X}$, wariancję $s_{x}^{2}$, odchylenie standardowe $s_{x} ;$

- wyznaczyć (gdy trzeba) korelację, np. związki cechy zmiennej X i innych cech osiągnięć i zachowania uczniów;

- wykonać estymację (szacowanie) punktową i przedziałową parametrów badanej populacji uczniów na podstawie statystyk próby losowej (np. średniej osiągnięć $\bar{X}$ ) i ocenić;

- przedziały ufności parametrów;

- wysunąc hipotezę badawcza typu "jeśli tegoroczne osiągnięcia nie różnią się od zeszłorocznych, to poziom osiągnięć uczniów można uważać za stabilny";

- sformułować hipotezy statystyczne, które są adekwatne hipotezie badawczej, np. hipoteza zerowa $\mathrm{H}_{0}$ : o tym, że "tegoroczny poziom średni $\bar{X}$ nie różni się od wartości średniej $\mu$ zeszłych lat" czyli $H_{0}:=\mu$, przeciw odpowiedniej 
hipotezie alternatywnej $\mathrm{H}_{1}$ :o tym, że "tegoroczny poziom średni $\bar{X}$ różni się od wartości średniej $\mu$ ubiegłych lat" czyli $\mathrm{H}_{1}: \neq \mu$;

sprawdzić (gdy trzeba) odpowiedniość rozkładu empirycznego zmiennej X rozkładowi normalnemu;

- wyznaczyć statystyke testowania hipotez (w wypadku średnich arytmetycznych stosujemy z-test albo test t-Studenta);

- wykonać sprawdzenie hipotez statystycznych na podstawie wybranych testów na poziomie istotności, np. 0,05;

- sformułować wnioski statystyczne co do przyjęcia/odrzucania hipotezy zerowej $\mathrm{H}_{0}:$;

- przejść od wniosków statystycznych do interpretacji wniosków merytorycznych;

- $\quad$ sformułować wnioski badawcze.

Uogólnienie wyliczonych wyżej procedur daje możliwość stwierdzenia, że stosowanie metod statystyki matematycznej w badaniach pedagogicznych składa się z trzech głównych bloków (części):

- przejście od obiektu realności pedagogicznej do abstrakcyjnego schematu matematycznego, tj. do modeli prawdopodobieństwa zjawiska, procesu, właściwości;

- dokonanie obliczeń środkami matematycznymi w ramach modeli na podstawie wyników eksperymentu (obserwacji, pomiarów itp.), formułowania wniosków statystycznych;

przejście od wniosków statystycznych do wnioskowań merytorycznych realnej sytuacji, interpretacji i podejmowania odpowiedniej decyzji co do problemów badawczych.

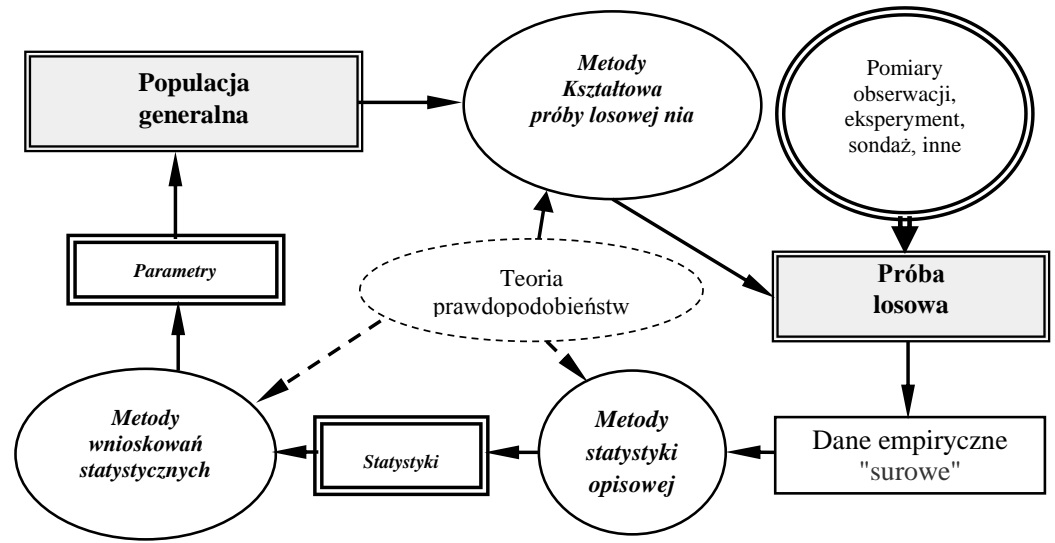

Rysunek 2. Schemat stosowania metod statystyki matematycznej.

Możemy zauważyć, że statystyka matematyczna opiera się na teorii prawdopodobieństwa, która jest jej podstawą (rysunek 1). Bez fundamentalnych pojęć i prawidłowości teorii prawdopodobieństwa uogólnianie wniosków statystyki a również i uzasadnione ich użycie dla celów naukowych i praktycznych są niemożliwe. Na przykład, zadaniem statystyki opisowej jest przekształcenie danych empirycznych na system wskaźników - statystyk - rozkładów częstości, miar 
tendencji centralnej i zmienności, współczynników związku itp. Jednak statystyki są charakterystykami próby (konkretnej zbiorowości). Można prezentować rozkłady, charakteryzować tendencje i zróżnicowania zmiennych konkretnej zbiorowości, lecz taka "analiza danych" ma ograniczoną naukowo-poznawczą wartość. Przenoszenie "mechanicznie" podobnych wniosków, uzyskanych na podstawie takich wskaźników, na inne całokształty obiektów badania nie jest poprawnym działaniem.

Wnioski i perspektywy dalszych badań. W statystyce matematycznej można wydzielić dwa równoległe rzędy wskaźników: pierwszy rząd kategorii (wskaźniki zbiorowości realnej) odnosza się do praktyki a drugi rząd (wskaźniki modelu prawdopodobieństwa) bazuje się na teorii. Na przykład, rozkładowi częstości empirycznej (praktyka) odpowiada pojęcie rozkładu prawdopodobieństwa (teoria); wartości średniej zmiennej zbiorowości (praktyka) odpowiada oczekiwanie matematyczne (teoria) itd. W badaniach empirycznych wskaźniki prób losowych (statystyki), z reguły, przyjmuje się za pierwotne. Wyznacza się je za pomocą obserwacji, pomiarów, eksperymentów itd. $\mathrm{Na}$ ich podstawie wskaźniki populacji generalnej (parametry) poddaje się procedurom szacowania statystycznego oraz sprawdzenia hipotez statystycznych. Statystyki przyjmują, z pewnym prawdopodobieństwem ryzyka (poziomem istotności), jako parametry - wskaźniki właściwości badanej populacji generalnej.

Ostatecznie, pedagog w swojej działalności nierzadko jest zmuszony mieć do czynienia $\mathrm{z}$ dużą ilością informacji empirycznej i budować swoje wnioski w warunkach nieokreśloności. Taka sytuacja charakteryzuje się wielością obiektów realności pedagogicznej. Z reguły, one są stochastyczne ze swoją przyrodą, ich zachowaniu jest właściwa pewna nieokreśloność, a faktem - losowość. Dlatego badania pedagogiczne $\mathrm{z}$ użyciem matematyki przeważnie wykonuje się $\mathrm{z}$ dołączeniem metod statystyki matematycznej. Jak pisze profesor Fred Kerlinger: "przeprowadzić kompetentne badanie albo przeczytać i zrozumieć sprawozdania naukowe, nie opanowawszy teorii prawdopodobieństwa i myślenia statystycznego, jest niemożliwe (Kerlinger, 1964, p. 9.).

\section{LISTA UŻYWANYCH ŹRÓDEŁ:}

Petty, W. (1691). Political Arithmetic or A Discourse Concerning the Extent and Value of Lands, People, Buildings... As the Same Relates to Every Country in General, but More Particularly to the Territories... of Great Britain and... of Holland, Zealand, and France. - London : Printed for Robert Clavel at the Peacock, and Hen. Mortlock at the Phoenix... (1691). - [24], 117, [3] s. 8.

Trzecia chrestomatia z historii teorii prawdopodobieństwa i statystyki // [online] http://www.sheynin.de/download/Chrestomatia_3.pdf

Quetelet, A. (XIX st.). Social fizyka, lub doświadczenie w pracy nad rozwojem zdolności ludzkich.

Ketle, A. (1911-13). Social fizyka, lub doświadczenie $w$ pracy nad rozwojem zdolnośc iludzkich. T. 1-2, - Kyjów.

Siegel, S. (1956). Nonparametric Statistics for the Behavioral Sciences. New-York: McGrow-Hill.

Glass, G., Stanley, J. (1970). Statistical Methods in Education and Psychology. Prentice-Hall, Inc., Enhlewood Cliffs, New Jersey.

Guilford, J.P. (1964). Podstawowe metody statystyczne w psychologii i pedagogice. Warszawa: PWN.

Góralski, A. (1980). Metody opisu i wnioskowania statystycznego w psychologii $i$ pedagogice. Warszawa: PWN. 
Brzeziński, J. (1996). Metodologia badań psychologicznych. Warszawa: PWN.

Ferguson, G. A. \& Takane, Y. (1997). Analiza statystyczna $w$ psychologii $i$ pedagogice. Warszawa: PWN

Ledniow, W. (2002). Edukacja naukowa: rozwój zdolności do twórczości naukowej. Moskwa: MGAU, p. 7

Rubacha, K. (2008). Metodologia badań nad edukacja. Warszawa: Wydawnictwa Akademickie i Profesjonalne, s. 34-37. s. 37-44.

Brzeziński, J. (2003). Metodologia badań psychologicznych. Warszawa: PWN,

King, B. \& Minium, E. (2009). Statystyka dla psychologów i pedagogów. Warszawa: PWN

Francuz, P. \& Mackiewicz R. Liczby nie wiedza, skąd pochodzą. Przewodnik po metodologii i statystyce. Lublin: Wydawnictwo KUL.

Stevens, S. On the Theory of Scales of Measurement // Science Vol. 103, No. 2684., p. 677-680.

Campbell, D. \& Stanley, J. (1963), Experimental and Quasi-experimental Designs for Research on Teaching. In N. Gage (Ed.), Handbook of research on teaching Chicago: Rand-McNally, p.171-246.

Granino, A., Korn \& Theresa. M. (2000). Mathematical Handbook for Scientists and Engineers: Definitions, Theorems, and Formulas for Reference and Review. Courier Dover Publications, s. 665.

Kerlinger, F. (1964). Foundations of Behavioral Research. Holt, Rinehart and Winston, New York, p. 9.

\section{REFERENCES:}

Petty, W. (1691). Political Arithmetic or A Discourse Concerning the Extent and Value of Lands, People, Buildings... As the Same Relates to Every Country in General, but More Particularly to the Territories... of Great Britain and... of Holland, Zealand, and France. - London : Printed for Robert Clavel at the Peacock, and Hen. Mortlock at the Phoenix... (1691). - [24], 117, [3] s. 8. [in English]

Trzecia chrestomatia $z$ historii teorii prawdopodobieństwa $i$ statystyki [The Third Chrestomathy in the History of Probability Theory and Statistics] [online] // http://www.sheynin.de/download/Chrestomatia_3.pdf [Accessed 20/02.18]. [in Polish]

Ketle, A. (1911-13). Social fizyka, lub doświadczenie $w$ pracy nad rozwojem zdolnośc iludzkich [Social Physics, or Experience in Working on the Development of Ilsumic Abilities]. T. 1-2, - Kyjów. [in Polish]

Siegel, S. (1956). Nonparametric Statistics for the Behavioral Sciences. New-York: McGrow-Hill. [in English]

Glass, G., Stanley, J. (1970). Statistical Methods in Education and Psychology. Prentice-Hall, Inc., Enhlewood Cliffs, New Jersey. [in English]

Guilford, J.P. (1964). Podstawowe metody statystyczne w psychologii i pedagogice [Basic Statistical Methods in Psychology and Pedagogy]. Warszawa: PWN. [in Polish]

Góralski, A. (1980). Metody opisu i wnioskowania statystycznego w psychologii $i$ pedagogice [Methods of Description and Statistical Inference in Psychology and Pedagogy]. Warszawa: PWN. [in Polish]

Brzeziński, J. (1996). Metodologia badań psychologicznych [Methodology of Psychological Research]. Warszawa: PWN. [in Polish]

Ferguson, G.A. \& Takane, Y. (1997). Analiza statystyczna $w$ psychologii $i$ pedagogice [Statistical Analysis in Psychology and Pedagogy]. Warszawa: PWN [in Polish]. 
Ledniow, W. (2002). Edukacja naukowa: rozwój zdolności do twórczości naukowej [Scientific Education: Development of the Ability to Scientific Creativity]. Moskwa: MGAU, p. 7 [in Polish]

Rubacha, K. (2008). Metodologia badań nad edukacja [Methodology of Research in Education]. Warszawa: Wydawnictwa Akademickie i Profesjonalne, s. 34-37. [in Polish]

Brzeziński, J. (2003). Metodologia badań psychologicznych [Methodology of Psychological Research]. Warszawa: PWN, s. 37 - 44. [in Polish]

King, B. \& Minium, E. (2009). Statystyka dla psychologów i pedagogów [Statistics for Psychologists and Pedagogues]. Warszawa: PWN. [in Polish]

Francuz, P. \& Mackiewicz R. Liczby nie wiedza, skąd pochodza. Przewodnik po metodologii $i$ statystyce [The Numbers do not Know Where They Come from. Guide to Methodology and Statistics]. Lublin: Wydawnictwo KUL. [in Polish]

Stevens, S. On the Theory of Scales of Measurement // Science Vol. 103, No. 2684. ,p. 677-680. [in Polish]

Campbell, D. \& Stanley, J. (1963), Experimental and Quasi-experimental Designs for Research on Teaching. In N. Gage (Ed.), Handbook of research on teaching Chicago: Rand-McNally, p.171-246. [in English].

Granino, A., Korn \& Theresa. M. (2000). Mathematical Handbook for Scientists and Engineers: Definitions, Theorems, and Formulas for Reference and Review. Courier Dover Publications, s. 665. [in English]

Kerlinger, F. (1964). Foundations of Behavioral Research. Holt, Rinehart and Winston, New York, p. 9. [in English]

\title{
МЕТОДОЛОГІЯ ЗАСТОСУВАННЯ МАТЕМАТИЧНОЇ СТАТИСТИКИ В ПЕДАГОГІЧНИХ ДОСЛІДЖЕННЯХ
}

\author{
Руденко Володимир \\ доктор габілітований, професор \\ Вищої школи менеджменту у Варшаві, \\ завідувач кафедри педагогіки, \\ м. Варшава, Польща \\ ORCID: 0000-0001-5986-264X \\ e-mail:vrudenko2004@gmail.com
}

\begin{abstract}
Анотація. Математизація наукових досліджень вважається характерною рисою сучасної науки. Нині спостерігається прискорений розвиток фундаментальних концепцій, аналітико-якісних і порівняльно-кількісних методів вивчення емпіричних даних, систематичне використання потенціалу комп'ютерної техніки, що значною мірою розширює можливості наукового пізнання. Цілком природно, що і сучасний педагог повинен володіти усім існуючим арсеналом науки. Сучасна педагогіка значною мірою перейшла від періоду накопичення емпіричного матеріалу до його систематизації, узагальнення, усвідомлення, структурної інтерпретації. Використання математичних методів в педагогіці полягає в підготовці, обробці, аналізі й інтерпретуванні даних з метою отримання відповіді на поставлене питання, зроблене припущення, сформульовану гіпотезу. Математика дозволяє поліпшити розуміння вже відомих явищ і процесів навчання і виховання. Застосування математики в педагогіці пропонується розглядати системно і як метод науково обгрунтованих оцінок педагогічної діяльності i засіб посилення евристичних можливостей; і як символьну форму побудови моделей педагогічної реальності; і як перспективний підхід прогнозування розвитку освітніх систем 3 метою їх оптимізації. У статті представлено методологічні підстави використання
\end{abstract}


математичних методів у педагогіці. Розкрито умови застосування математичної статистики на різних етапах організації і виконання досліджень в галузі освіти: формування вибірки, визначення основних показників описової статистики в ході умовиводів 3 використанням статистичних висновків, методів кореляційного i регресійного аналізу, дисперсії та інших чинників.

дослідження.

Ключові слова: статистика, методологія, метод, освіта, педагогіка,

\title{
METHODOLOGY OF IMPLEMENTATIOM THE MATHEMATICAL STATISTICS IN PEDAGOGICAL RESEARCH
}

\author{
Volodymyr Rudenko \\ Doctor Habilitated, Professor, \\ Higher School of Management in Warsaw, \\ Head at the Department of Pedagogy, \\ Warsaw, Poland \\ ORCID: 0000-0001-5986-264X \\ e-mail: vrudenko2004@gmail.com
}

\begin{abstract}
Mathematization of scientific research is considered a characteristic feature of modern science. Currently there is an accelerated development of fundamental concepts and applied systems, analytical and qualitative and comparative-quantitative methods for studying empirical data, systematic use of the potential of computer technology, which greatly expands the possibilities of scientific knowledge. It is entirely natural that a modern educator should possess all the existing arsenal of science. Pedagogical research involving mathematics aimed at determining the leading properties of educational activity, the identification of the laws of formation and development of personality.Modern pedagogy has largely shifted from the period of accumulation of empirical material to its systematization, generalization, awareness, structural interpretation. The use of mathematical methods in pedagogy consists in the preparation, processing, analysis and interpretation of data in order to obtain an answer to the question posed, an assumption made, a hypothesis formulated. Along with the methodology and theory, mathematics is an effective tool through which you can improve your understanding of already known phenomena and processes of education and education.The use of mathematics in pedagogy is proposed to be considered systematically and as a method of scientifically based assessments of pedagogical activity and a means of strengthening heuristic opportunities; and as a symbolic form of constructing models of pedagogical reality for its study and improvement; and as a promising approach to forecasting the development of educational systems in order to optimize them. The methodological grounds for using mathematical methods in pedagogy are presented. The conditions of application of mathematical statistics at different stages of organization and implementation of research in the field of education are revealed: the formation of a sample, the definition of the main indicators of descriptive statistics during the inferences with the use of statistical conclusions, methods of correlation and regression analysis, variance and other factors.
\end{abstract}

Keywords: statistics, methodology, method, education, pedagogy, research.

Стаття надійшла до редакиії 20.03.2019 р. 